\author{
Andrzej Jastrzębski OMI ${ }^{1}$ \\ 0000-0003-2637-7706 \\ Sant Paul University in Ottawa
}

\title{
About some limitations in researching the human being. Theological perspective
}

Any research on the human being has to be done in a very careful way. Since in this unique situation, the human being is both the object and subject of the study. We are not able to be fully objective toward the object of the study because, naturally, we compare and apply the outcomes of such research to ourselves.

How a person is defined has gone through several stages of development in the history of thought. In the classical tradition, a person is considered to be a substance. This is Boethius's understanding of a person as "an individual substance of a rational nature." In modernity, John Locke brought forward the notion that social existence and consciousness are the most salient properties of a person, which generated a risk

1 Andrzej Jastrzębski O.M.I. - professor at Saint Paul University in Ottawa, holds a post-graduate diploma in Psychotherapy and Pastoral Counseling, a PhD in Metaphysics and Philosophical Anthropology, and a habilitation in Spiritual Theology. He has authored several books, written a number of articles, and given many talks on anthropological issues touching spirituality, philosophy and psychology. E-mail: andrzej.jastrzebski@oblaci.pl. 
of renouncing one's personhood because of a lack of some perceivable and observable traits.

This is why, in Christian anthropology, there is such an emphasis on personalism, which from the very beginning of the $20^{\text {th }}$ century has been opposed to the treatment of people as obscure elements of matter, or elements to be manipulated unquestioningly. The dominant techno-pragmatic culture of our time, with its undisputed accomplishments, seems set to remain the highest authority on our nature and our aspirations as persons. But we want to be considered as unique and valuable persons, and not simply elements of a large, complex social machine.

In the twentieth and twenty-first centuries, this has supported a terrible phenomenon that has cost many people their lives: the cult of personality. Using the most recent results of social psychology and the massive leverage available to some political systems, dictators have subjugated peoples and turned them against each other, to the detriment of human dignity.

Another type of threat to humanity, today, is the new and globalized society that has stripped people of their will, largely through their own consent. They have become involved with pleasure and competition in a variety of ways established by social convention or current fashion. Personalism should be seen as an antidote offered to the contemporary world, to help us preserve our uniqueness, dignity, and autonomy.

In this paper we will indicate some elements of anthropology that demonstrate the important limitation of any attempt at explaining away the mystery of being human person.

\section{Theological personalism}

To a large extent, contemporary humanity is frustrated, turned inwards, left alone and deprived of subjectivity. Modern psychology doesn't help us to haul ourselves out of this confined world or give us spiritual maturity. The litmus test for such maturity is the capacity to engage in a deep and nurturing relationship with another person. The lack of spiritual maturity can be masked by activities that limit us to 
the world of things, and when they vanish we are faced again with our loneliness.

To address this challenge existentialist personalism focuses on self-actualization. It agrees with the definition of a person offered by Boethius. However, it fails to underline the communion expressed most fully in love. First initiated by existentialist philosophers, and further developed by psychologists, communion as expressed in love reflects on liberty and personal responsibility in regard to one's major choices, and testifies to the importance of becoming truly human. The encounter with another is often seen by existentialist thinkers more as a threat than an opportunity. While communitarian personalism also insists on the importance of individual freedom, it understands the need to connect with and take responsibility for another "Thou." Without love, freedom can be destructive.

Many types of personalism have developed along with the world and its history, but first and foremost, in opposition to the nature and the role of the human body. They represent the temptation to escape into "spiritualism," an overestimation of human spirituality. It is easy to illustrate and defend a privileged position for the human mind, flowing from human dignity in comparison with the entire world of nature. These types of personalism see our carnality with suspicion, viewing it as being in conflict with true spiritual existence. A more adequate concept of our existence is twofold: carnal and spiritual. It has to be the entire human being who loves and not simply the pure spirit. Though the human body can become the anchoring point for a materialist theory, it is nonetheless an element in the structure of the whole human being. The absolutization of the body is dangerous, but so too is the absolutization of the spirit. The body receives its personal dignity indirectly, being instrumental to developing interpersonal relationships, and consequently strengthening the community. The body enables the soul to express love in the full sense of its emotional energy; however, the body needs to be educated in a specific way. ${ }^{2}$

2 B. Häring, Personalismo in teologia e filosofia, Roma 1969, p. 41-42; A. Jastrzębski, (Nie)obecność ciała $w$ wybranych koncepcjach psychologicznych i filozoficznych, in: 
Theologically speaking we know that the human being and God reveal themselves as beings of totally different natures. It is not easy to overcome such a huge difference; to establish a relationship with God is a great challenge. Such a relationship is possible, however, since we share personhood with God. The belief in our personhood is the key to anthropology, since it reveals our immateriality. Otherwise, it would be difficult to explain the undeniable quest for "something more" something beyond our known reality.

Ultimately, theological personalism reveals our true personal nature, that of others, and of God. It unites these three into one indissoluble whole. For God is not only the creator of the world, and of ourselves, but also a loving friend.

Contemporary personalism has been under constant threat from instrumentalism - be it social or scientific - in the undisguised tendency to control reality with more and more inventions and increasingly efficient tools. ${ }^{3}$

\section{The dimension of the encounter}

To get to know another human being, one needs to possess a capacity for sympathy that is just the reverse of the trend towards objectivization in contemporary science. Sympathy implies the acceptance of the other as someone who always transmits some message. ${ }^{4}$ Sympathy is another important characteristic of a solid anthropology.

The sympathetic discovery of another person occurs only in a relationship, as the discovery of another "Thou." We meet our self as a living person in an authentic encounter with a "Thou." According to Martin Buber, a major flaw of contemporary anthropology lies in the exacerba-

Człowiek - Medycyna - Wartości, red. E. Starzyńska-Kościuszko, A. Kucner, Olsztyn 2014, p. 195-210.

3 B. Häring, Personalismo in teologia e filosofia, op. cit., p. 11.

4 M. Buber, I and Thou, transl. W. A. Kaufmann, New York 1970.

5 M. Buber, Eclipse of God: Studies in the Relation Between Religion and Philosophy, Atlantic Highland 1988, p. 44-45. 
tion of individuality. As a result, we've lost sight of the complete picture of selves. Buber opposes the practice of breaking a person down into parts and investigating the parts separately. This gives us the wrong idea of our nature. Openness to an encounter, to meeting another, then, is of the utmost importance.

The human being is not exclusively a self nor do we possess a self, but, as subjects of experience, we escape all forms of objectification. The self exists in relation to other selves and to objects - the first type of relationship implies openness to another's existence while the second is closed to another self. Since we're always moving between these two types of relationship, with persons and with objects, we are continually in statu fieri (being in the process of accomplishment). But those who respond to the meaning and life of the world take responsibility both for the world and for themselves. They reject the temptation of indifference, of reifying the other. Indifference comes with being "outside" of the other's life without any commitment to the fate of the other. A person cannot be solely in a relationship with objects (I-it). Being caught up in the order of objects makes it impossible to become truly human. Full human development is only possible with the courage to reach out to another self, the courage of encounter.

Among the most important problems of our contemporary world, however, is alienation, the inability to connect with others. Throughout our lives we define ourselves by the way we enter into dialog with other, similar or different people, the created world, and providence. Often dialog with others or with the world gives us no accessible and precise definition of ourselves and we are left with fragments. Indeed, if I can try to express what the most harmful situation a human person can be subjected to, it must be what prevents them from encountering another person in an authentic relationship. An authentic relationship between people depends on their viewing each other as having the same, ultimate value.

To develop a good understanding of ourselves, we have to consider the categories of dialog and the "I-Thou" relationship. Properly understood dialogism (not solipsism) leads to the act of self-transcendence that takes us beyond ourselves. And for this, I and Thou must both be unique. Genuine encounter is not the meeting of two identical monads, but a sharing 
of sense and meaning. This means a sincere reciprocal attention, transcending people's "ontological deafness" - their inability to listen to one another. ${ }^{6}$

The full discovery of our identity takes place through contacts with other persons. In more concrete terms, it starts with the encounter of another person and with the acknowledgement of this person as a gift. This is the real basis of individual freedom. Beyond contacts with other persons, the encounter with God as a person is of crucial importance. Entering into a profound relationship with God often leads to a transformation of one's life, and to the experience of infinite love. In fact, the most profound experience a person can have occurs in and through love, because it is the best way to encounter another "Thou".

Buber says that someone is a person only because surrounded by others similar to themselves. ${ }^{7}$ The existentialist psychologist van Kaam would say that "every encounter, makes the other be in some way. The way in which I make the other be is very much determined by the kind of encounter we have."

Van Kaam goes further:

It is totally impossible for me to think about any mode of being in which I am perfectly alone. All my modes of being in the world are influenced by the existence of others. Others make me be, and I make others be. The reality which I am is not an isolated reality independent of others. I can only understand myself as born from the other, or as nourished and educated by the other, as speaking the language the other speaks, as wearing clothing that is created by others, or as having customs generated by many others before me. ${ }^{9}$

The point for van Kaam is that each of us must stay in open dialog with reality. This dialog would mean being open to the world as it reveals itself in our daily circumstances. Otherwise, the lack of such dialog would

6 V. E. Frankl, The Will to Meaning. Foundations and Applications of Logotherapy, New York 1988, p. 89.

7 M. Buber, The Writings of Martin Buber. Selected, edited, and translated by Will Herberg, New York 1956, p. 63-88; M. Theunissen, Personalismus, in: Historisches Wörterbuch der Philosophie, Hrsg. J. Ritter, K. Gründer, Bd. 7, Basel 1989, p. 339.

8 A. Van Kamm, The Art of Existential Counseling, Pennsylvania 1966, p. 46.

9 A. Van Kamm, The Art of Existential Counseling, op. cit., p. 48. 
close us off from reality - a rejection of its voice, which is ultimately the voice of truth. ${ }^{10}$

Similarly, Rollo May insists on the need for dialogism in human existence, saying that the authentic encounter with another person always drastically reorganizes the world of our relationships as well as our comfortable, quiet lives, and leads to the issue of our openness and readiness for change. ${ }^{11}$ Paul Tillich adds that being a person means questioning our own existence and living according to the answers we give. ${ }^{12}$

To summarise, let us turn to Wilfrid Stinissen who postulates that we discover ourselves only when we can see ourselves in the loving eyes of another person. It is very difficult to get to know ourselves while living alone ${ }^{13}$ Hence, the dimension of encounter is another major point for anthropological reflection.

\section{Against determinism in understanding the human being}

We propose to acknowledge Victor Frankl's concept of multidimensionality as an important characteristic of an anthropology that is selfaware of its limitations. Frankl considered that, compared with science, philosophy is the only discipline capable of providing a complete account of human existence. We are also aware that the ultimate, yet not definitive, understanding of the human being comes from theology. Frankl underlines that the natural sciences offer only very specific, thus limited account of their understanding of the human being, dooming their research to a certain failure. Even though they pretend to produce a full vision of our existence, their outcome invariably leads to reductive accounts - an organism, a mechanism, or a process of socialization. Frankl is emphatic on this common tendency in the sciences, while acknowledging their contribution to knowledge.

\footnotetext{
A. Van Kamm, The Art of Existential Counseling, op. cit., p. 73.

11 R. May, The Emergence of Existential Psychology, in: Existential Psychology, ed. R. May, New York 1961, p. 40.

12 P. Tillich, Pytanie o Nieuwarunkowane, przekł. J. Zychowicz, Kraków 1994, p. 81.

13 W. Stinissen, Człowiek prawdziwy, przekł. J. Iwaszkiewicz, Poznań 2013, p. 80.
} 
To illustrated this challenge Frankl has conducted a quite interesting, philosophical analysis of human existence that has greatly surpassed the other accomplishments of psychology. It is sometimes called "meta-clinical analysis." His vision of the human being offers a more comprehensive account of our existence than psychology. Philosophy can help psychology in the task of establishing and improving standards for the study of human nature.

To better present his concept of the human being, Frankl sets out two laws of what he called "dimensional ontology." ${ }^{14}$ He explains the first law of dimensional ontology as follows: when we project from a cylinder onto two flat planes facing the top and the side, we get a two-dimensional circle on one of these planes and a rectangle on the other. This enables us to understand the highly specialized nature of contemporary science. We have two distinct pictures, yet both are true. To integrate these two aspects into a more adequate concept of human existence we need to climb over them and reach a higher level and see everything in a much larger perspective, as we do in philosophy as well as in theology. Consistent with the second law of dimensional ontology, three different solid figures look alike when projected from the base onto a single two-dimensional plane: a cylinder, a cone, and a ball all appear as a two-dimensional circle. In this way Frankl explains the incapacity of the sciences within the scope of their own standards and practices to consider all aspects of the human being. As an example, Frankl indicates religion: on a psychological plane, it is reduced to a psychic phenomenon.

The fragmentary scientific concepts of human existence - such as behaviourism, psychoanalysis, or Pavlovian conditioning - represent lower, two-dimensional levels of description. Even if they do not stand in opposition to the holistic concept, they cannot provide an account of the wholeness of human existence. Only a three-dimensional concept of the human being provides a complete picture. ${ }^{15}$

14 V. E. Frankl, The Will to Meaning, op. cit., p. 23.

15 V. E. Frankl, The Will to Meaning, op. cit., p. 26. 
The significance of the second law of dimensional ontology can be illustrated with the example of neurosis. According to Frankl, this pathology can have several sources, several aetiologies. There are, for instance, psychogenic neurosis, somatogenic neurosis, and noogenic neurosis. The latter is Frankl's contribution to understanding neurosis, which, in his eyes, is a spiritual neurosis linked to the losing of life's meaning. Frankl relates it to spiritual problems, moral conflicts, and problems concerning the meaning of life expressed through the need to overcome existential emptiness. ${ }^{16} \mathrm{Opting}$ for a two-dimensional or a unidimensional approach to human suffering impacts negatively on our dignity as human beings. For instance, the mechanical model of the human being treats us as objects to be fixed, and not as self-conscious subjects of experience nor beings capable of discovering meaning. ${ }^{17}$

The significance of the second law of dimensional ontology can be illustrated with reference to Joan of Arc. Keeping in mind the voices she heard and the frequent hallucinations she had, it would be possible to diagnose the saint as a clear case of schizophrenia. Only from a three-dimensional perspective, can we see her real meaning in history and theology. In this perspective, Joan of Arc appears with a much larger stature than that of a schizophrenic. ${ }^{18}$ Another example can be found in St. Theresa of Lisieux, who, despite her suffering from Separation Anxiety Disorder, was able to develop a sound spiritual life. ${ }^{19}$

A higher level of description obviously allows a better view of reality because it contains in itself the lower levels. We obtain a better account of the lower level from the higher one, in which the former remains somewhat hidden. From this standpoint, we can say that biology is better explained by psychology, psychology by noology, and noology by theology. ${ }^{20}$

16 V. E. Frankl, The Will to Meaning, op. cit., p. 27.

V. E. Frankl, The Will to Meaning, op. cit., p. 28.

18 V. E. Frankl, The Will to Meaning, op. cit., p. 29.

19 P. C. Vitz, C. P. Lynch, Thérèse of Lisieux From the Perspective of Attachment Theory and Separation Anxiety, "The International Journal for the Psychology of Religion" 17/1 (2007), p. 61-80. http://dx.doi.org/10.1080/10508610709336854.

20 V. E. Frankl, Man's Search for Ultimate Meaning, New York 2000, p. 16. 


\section{Cataphatic-apophatic dimension of anthropology}

The last point regarding the limits of any anthropology is that there will be always a space of unknown regarding the human being. Awareness of this fact was more present in the early years of the church. Athanasius of Alexandria, Basil, Gregory of Nazianzus, and other fathers of the church tried to purify the theology of the Hellenistic tradition. While doing this, they developed a Christian apophaticism that aimed to turn speculative thinking towards the contemplation of the mystery of the Holy Trinity. In apophatic theology, God remains hidden - Deus absconditus. ${ }^{21}$ As the image of God, the deepest nucleus of our existence, our spiritual existence, likewise remains hidden to us. Thus, we can speak, analogously, of homo absconditus or of apophatic anthropology.22

St. Augustine opposed the attempt to define our nature, because every such attempt is inevitably fraught with the risk of reductionism, be it by oversimplification or through the neglect of constitutive elements. We cannot describe our personal nature from the outside with the help of Aristotelian categories. Augustine says that such a procedure leaves no room for mystery; we should turn to God in order to understand our nature "without any eclipse". ${ }^{23}$

Gabriel Marcel elaborated on this point as follows:

If this is so, it must be seen that the personality cannot in any way be compared to an object of which we can say it is there, in other words that it is given, present before our eyes, that it is part of a collation of things which can, of their essence, be counted, or again, that it is a statistical unit which can be noted in the calculations of a sociologist employing the methods of an engineer. Or again, if we no longer consider things from outside but from within, that is to say from the point of view of the person himself, it does not seem that strictly speaking he can say "I am" of himself. He is aware of himself far less as a being than as a desire

${ }^{21}$ V. Lossky, The Mystical Theology of the Eastern Church, transl. Fellowship of St. Alban and St. Sergius, London 1957, p. 50.

22 P. Evdokimov, Woman and the Salvation of the World, transl. A. P. Gythiel, Crestwood 1994, p. 44.

${ }_{23}$ St. Augustine, The Confessions of St. Augustine, transl. and annoted by J. G. Pilkington, New York 1943, p. 80-82. 
to rise above everything which he is and is not, above the actuality in which he re-

ally feels he is involved and has part to play, but which does not satisfy him, for it falls short of the aspiration with which he identifies himself. ${ }^{24}$

For Marcel, as for Augustine, the human being remains a mystery. This does not mean that we cannot know ourselves, but rather that there always looms the possibility of "degrading" the mystery of our existence or of transforming it into a "problem," a problem to be resolved by our own efforts. Marcel sees this as a fault of contemporary academic mentality. ${ }^{25}$

With our science we do not create values, but we revive and embody them. Through our subjective experience, we seem to shape ourselves, that is, we seem to establish our personal values, but, from an ontological point of view, they were ours from the very beginning. We can only expand on this knowledge. We are, as we suggested earlier, homo absconditus. Only the discovery of the revealed truth about our nature allows us to live more fully. ${ }^{26}$ The cataphatic side of Christian anthropology, where we assert something, has to coexist with an apophatic side that admits the mystery.

\section{Conclusion}

We can point to an artificial division of the ontological and epistemological orders. Let us explain. Left to ourselves and being at the same time the inquirer and the object of inquiry, we do not have the necessary distance for scientific objectivity in regard to ourselves. This explains why it is so easy to make serious mistakes concerning the understanding of our existence and, consequently, the human being generally. Only a superior spiritual being could take a fully objective view of human nature - and here we are referring specifically to God. A distant echo of the difficulty we have of getting to know our true nature is found

\footnotetext{
G. Marcel, Homo Viator, transl. E. Craufurd, London 1951, p. 25-26.

G. Marcel, Being and Having, transl. K. Farrer, London 1965, p. 185-189.

26 P. Evdokimov, Woman and the Salvation of the World, op. cit., p. 49.
} 
in Heisenberg's principle of indeterminacy. As we cannot in the same moment know the location and the speed of an electron, so we cannot know at once the pure self (like Husserl) and its content. We are, likewise, an enigma to ourselves, as it is in our nature to be witness both to the whole world and to our relationship to it. By itself, our existence is a good illustration of the discontinuities and of the incompleteness of the world of nature where we are directed to a higher reality than ourselves. Since we are thus related to two different orders - the ontological and epistemological - we have the ability to self-transcend, but without theological knowledge, it only makes us a paradoxical entity, full of inner contradictions and of conflicts between several tendencies.

We know from experience that the human person can be both compassionate and cruel, clever and stupid, just and greedy, free and unfree. We possess a distorted nature but we have also a memory of our divine origins, because our roots are in God, and we are advancing towards God more or less consciously. As humans, we are not exclusively a by-product of blind natural forces, and we remain part of nature. We are still linked to some biological determinism, despite the fact that we can transform or bypass it. In our actions we become creators, creators of nature, creators of culture and of a new value in the natural world, which is why it is impossible to solve the problem of our nature by relating it solely to the results of natural science, without any relationship to God. We cannot understand ourselves with reference only to something "lower." The human being is the imago Dei, both as a fallen and as a ransomed creature.

Any well-grounded anthropology must limit itself in regard to the mystery of the human being, mysterium personae. However, theological anthropology illuminates, complements, and accurately identifies the humanist intuitions concerning human nature, in the final analysis every anthropology remains at the threshold of the mystery of the human being. Ignoramus et ignorabimus. This human fallibility indicates that the other can be right, and this leads to humility. 


\section{Summary}

About some limitations in researching the human being. Theological perspective

The concept of a person has gone through several stages of development in the history of thought. In the classical tradition, a person is considered to be a substance. In modernity, John Locke brought forward the notion that social existence and consciousness are the most salient properties of a person, which brought about a possibility of renouncing one's personhood because of a lack of some perceivable and observable traits. This is why in a Christian anthropology there is such an emphasis on personalism, which from the very beginning of the twentieth century has been opposed to the treatment of people as obscure elements of matter, or elements be manipulated unquestioningly. In this paper we have indicated some elements of anthropology that demonstrate important limitation of any attempt at explaining away the mystery of being a human person.

Keywords: human person, personalism, determinism, mystery

\section{O granicach w badaniu człowieka. Perspektywa teologiczna}

Pojęcie osoby przeszło wiele zmian w historii myśli ludzkiej. W tradycji klasycznej osoba jest uważana za substancję. W oświeceniu John Locke przedstawił pogląd, że egzystencja społeczna i świadomość są najważniejszymi właściwościami osoby, co spowodowało możliwość utracenia godności osobowej z powodu braku pewnych dostrzegalnych i możliwych do zaobserwowania cech. Właśnie dlatego w antropologii chrześcijańskiej kładzie się tak duży nacisk na personalizm, który od samego początku stanowi przeciwwagę wobec traktowania ludzi li tylko jako elementów materii, którymi można dowolnie manipulować. W niniejszym artykule przedstawimy taką charakterystykę antropologii, która ukazuje istotne ograniczenie wszelkich prób wyjaśnienia tajemnicy bycia człowiekiem.

Słowa kluczowe: osoba ludzka, personalizm, determinizm, mysterium

\section{Bibliography}

Häring B., Personalismo in teologia e filosofia, Roma 1979.

Jastrzębski A., (Nie)obecność ciała w wybranych koncepcjach psychologicznych i filozoficznych, w: Człowiek - Medycyna - Wartości, red. E. Starzyńska-Kościuszko, A. Kucner, Olsztyn 2014, s. 195-210.

Buber M., I and Thou, transl. W. A. Kaufmann, New York 1970. 
Buber M., Eclipse of God: Studies in the Relation Between Religion and Philosophy, Atlantic Highland 1988.

Frankl V. E., The Will to Meaning. Foundations and Applications of Logotherapy, New York 1988.

Buber M., The Writings of Martin Buber. Selected, edited, and translated by Will Herberg, New York 1956.

Historisches Wörterbuch der Philosophie, Hrsg. J. Ritter, K. Gründer, Bd. 7, Basel 1989.

Van Kaam A., The Art of Existential Counseling, Pennsylvania 1966.

May R., The Emergence of Existential Psychology, in: Existential Psychology, ed. R. May, New York 1961, p. 11-51.

Tillich P., Pytanie o Nieuwarunkowane, przekł. J. Zychowicz, Kraków 1994.

Stinissen W., Człowiek prawdziwy, przekł. J. Iwaszkiewicz, Poznań 2013.

Vitz P. C., Lynch C. P., Thérèse of Lisieux From the Perspective of Attachment Theory and Separation Anxiety, "The International Journal for the Psychology of Religion" 17/1 (2007), p. 61-80, http://dx.doi.org/10.1080/10508610709336854.

Frankl V. E., Man's Search for Ultimate Meaning, New York 2000.

Lossky V., The Mystical Theology of the Eastern Church, transl. Fellowship of St. Alban and St. Sergius, London 1957.

Evdokimov P., Woman and the Salvation of the World, transl. A. P. Gythiel, Crestwood 1994.

St. Augustine, The Confessions of St. Augustine, transl. and annoted by J. G. Pilkington, New York 1943.

Marcel G., Homo Viator, transl. E. Craufurd, London 1951.

Marcel G., Being and Having, transl. K. Farrer, London 1965. 